\title{
Erratum to: Neurocritical care update
}

Yasuhiro Kuroda

\section{Erratum}

Unfortunately, the original version of this article [1] contained several errors:

- Reference 24 in the original article (reference [2] in this erratum) should have been "Brophy GM, Human T, Shutter L. Emergency neurological life support: pharmacotherapy. Neurocrit Care. 2015;23(Suppl 2):S48-68" instead of "Badjatia N, Kowalski RG, Schmidt JM, Voorhees ME, Claassen J, Ostapkovich ND, Presciutti M, Connolly ES, Palestrant D, Parra A, et al. Predictors and clinical implications of shivering during therapeutic normothermia. Neurocrit Care. 2007;6(3):186-91".

- Reference 25 in the original article (reference [3] in this erratum) should have been "Badjatia N, Strongilis E, Gordon E, Prescutti M,Fernandez L, Fernandez A, Buitrago M, Schmidt JM, Ostapkovich ND, Mayer SA. Metabolic impact of shivering during therapeutic temperature modulation: the Bedside Shivering Assessment Scale. Stroke. 2008 Dec;39(12):3242-7. doi: 10.1161/STROKEAHA.108.523654. Epub 2008 Oct 16" instead "Brophy GM, Human T, Shutter L. Emergency neurological life support: pharmacotherapy. Neurocrit Care. 2015;23(Suppl 2):S48-68".

- Accordingly, the caption of Figure 1 that cited reference 24 and 25 was wrong too, and it should have been "Anti-shivering protocol example and the bedside shivering assessment scale. IV intravenous, PT per feeding tube, ECG electrocardiogram. Modified from Brophy [24] and Badjatia [25] with permission" instead of "Anti-shivering protocol example and the bedside shivering assessment scale. IV intravenous, PT per feeding tube, ECG electrocardiogram. Modified from Brophy [25] and Badjatia [24] with permission".

The references have been corrected in the original article and are also correctly included in this erratum.

Correspondence: kuroday@kms.ac.jp

Department of Emergency, Disaster, and Critical Care Medicine, Faculty of Medicine, Kagawa University, 1750-1, Ikenobe, Miki, Kita, Kagawa 761-0793, Japan

(c) 2016 The Author(s). Open Access This article is distributed under the terms of the Creative Commons Attribution 4.0 International License (http://creativecommons.org/licenses/by/4.0/), which permits unrestricted use, distribution, and reproduction in any medium, provided you give appropriate credit to the original author(s) and the source, provide a link to the Creative Commons license, and indicate if changes were made. The Creative Commons Public Domain Dedication waiver (http://creativecommons.org/publicdomain/zero/1.0/) applies to the data made available in this article, unless otherwise stated.
Received: 14 July 2016 Accepted: 14 July 2016

Published online: 25 July 2016

References

1. Kuroda Y. Neurocritical care update. J Intensive Care. 2016;4:36. doi:10.1186/s40560-016-0141-8.

2. Brophy GM, Human T, Shutter L. Emergency neurological life support: pharmacotherapy. Neurocrit Care. 2015;23 Suppl 2:S48-68.

3. Badjatia $N$, Strongilis E, Gordon E, Prescutti M, Fernandez L, Fernandez A, Buitrago M, Schmidt JM, Ostapkovich ND, Mayer SA. Metabolic impact of shivering during therapeutic temperature modulation: the Bedside Shivering Assessment Scale. Stroke. 2008;39(12):3242-7. doi:10.1161/ STROKEAHA.108.523654. Epub 2008 Oct 16.

Submit your next manuscript to BioMed Central and we will help you at every step:

- We accept pre-submission inquiries

- Our selector tool helps you to find the most relevant journal

- We provide round the clock customer support

- Convenient online submission

- Thorough peer review

- Inclusion in PubMed and all major indexing services

- Maximum visibility for your research

Submit your manuscript at
Biomed Central Surw biomedcentratcom/submit 